\title{
Acute Toxicity, Anti-ulcer and Anti-inflammatory Effects of Methanol Extract of Gladiolus segetum in Rats
}

\author{
Salah Eddine Marref*, Naima Benkiki, Mohamed Akram Melakhessou, Soumia Bouzidi
}

\section{Salah Eddine Marref*, Naima Benkiki, Mohamed Akram Melakhessou, Soumia Bouzidi}

Laboratoire de Biotechnologie des Molécules Bioactives et de la Physiopathologie Cellulaire. Université de Batna-2, 05000, ALGÉRIE.

Correspondence

Salah Eddine Marref

Laboratoire de Biotechnologie des Molécules Bioactives et de la Physiopathologie Cellulaire. Université de Batna-2, 05000, ALGÉRIE.

Phone no : +213770637011

E-mail: Salah.d.marref@hotmail.fr

History

- Submission Date: 25-10-2017;

- Review completed: 14-03-2018

- Accepted Date: 19-03-2018

DOI : 10.5530/pj.2018.4.127

Article Available online

http://www.phcogj.com/v10/i4

Copyright

(C) 2018 Phcog.Net. This is an openaccess article distributed under the terms of the Creative Commons Attribution 4.0 International license.

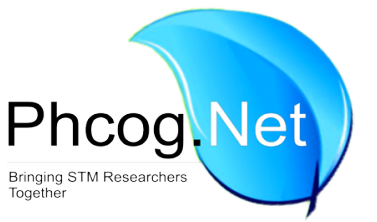

\begin{abstract}
Objectives: To evaluate the in vivo anti-ulcer and anti-inflammatory activities of methanol extract of the aerial parts of Gladiolus segetum. Methods: first methanol extract of Gladiolus segetum was subjected to the acute oral toxicity test according to the OECD, guideline no 423. The anti-ulcer activity of Gladiolus segetum was investigated by ethanol induced gastric ulcer in Wistar rats. Methanol extract was administered by gavage one hour before ethanol to the different groups at a dose corresponding of 100,250 and $500 \mathrm{mg} / \mathrm{kg}$ body weight. The control group received normal saline in comparable volume $(10 \mathrm{ml} / \mathrm{kg}$ body weight) by the same route. The anti-inflammatory activity of the tested extract was evaluated in adult wistar rats by the egg albumin induced paw edema method. Results: A significant reduction ( $p<0.001$ ) was observed in the results of the present study, revealed that methanol extract possessed gastroprotective activity and exerts a topical anti-inflammatory effect in vivo. Conclusion: These results suggest that methanol extract of Gladiolus segetum may represent an important clinical alternative in anti-inflammatory and antiulcer genic therapeutics.
\end{abstract}

Key words: Gladiolus segetum, Gastric ulcer, Antiulcer genic, Anti-inflammatory.

\section{INTRODUCTION}

Herbal medicine is the oldest form of healthcare known to human kind, plants have been used by all cultures throughout history. Medicine of plant origin is based upon the premise that plants contain natural substances that have forever been a catalyst in the healing process. $^{1}$

Ulcer and inflammation are diseases that affect millions of people worldwide. Gastric ulcer, one of the most widespread, is believed to be due to an imbalance between aggressive and protective factors. ${ }^{2}$ Inflammation is a process mediated by a variety of signalling molecules produced by cells, platelets, as well as by the activation of complement factors which bring about edema formation because of extravasation of fluid and proteins and accumulation of leukocytes at the inflammatory site. ${ }^{3}$

The aerial parts of Gladiolus segetum (Iridaceae) have been traditionally used for the treatment of various diseases of digestive system, infertility and other inflammatory affections in the Mediterranean region. The objective of this investigation was to evaluate the anti-ulcer and anti-inflammatory activities of the methanol extract from aerial parts of Gladiolus segetum

\section{MATERIALS AND METHODS}

\section{Collection of plant material}

Gladiolus Segetum was collected in May 2015 from Batna, Algeria and identified by Professor Bachir Oud(MEGS) in rats. jehih (department of Agronomic, university Batna1). The voucher specimen number is 183DAUB2004 was deposited in the herbarium of the above-mentioned department.

\section{Preparation of extract}

The aerial parts of Gladiolus Segetum were shade dried and powdered; $600 \mathrm{~g}$ of powder was macerated sequentially using hexane, chloroform, ethyl acetate, and methanol (Solvents of increasing polarity).

\section{Animals}

The study was carried out in healthy Wistar rats of both sex, weighing 120-205 g. The animals were obtained from the Institute Pasteur of Algeria. They were acclimated to the laboratory condition for 7 days before the experimental studies. The rats were housed in polypropylene cages under controlled conditions of light/dark ( $12 \mathrm{~h} / 12 \mathrm{~h})$ at temperature of $(23 \pm 2){ }^{\circ} \mathrm{C}$ under strict hygienic conditions. Standard food pellets and tap water ad libitum was used.

Acute oral toxicity study

Acute toxicity study was performed according to organization for economic co-operation and development (OECD) guidelines 423 (OECD, 2001) where the limit dose of $2000 \mathrm{mg} / \mathrm{kg}$ body weight (b.w.) was used. ${ }^{4}$
Cite this article: Marref SE, Benkiki N, Melakhessou MA, Bouzidi S. Acute Toxicity, Antiulcer and Anti-inflammatory Effects of Methanol Extract of Gladiolus Segetum in Rats. Pharmacog J. 2018;10(4):758-62. 
Female albino rats were divided into 2 groups $(n=5)$, control and test group. The animals were fasted for $24 \mathrm{~h}$ with free access to water only. Control group received normal saline $(0.9 \%)$ as vehicle at a dose volume of $10 \mathrm{~mL} / \mathrm{kg}$ b.w. whilst the test group received single oral dose of $2000 \mathrm{mg} / \mathrm{kg}$ b.w. of MEGS (10mL/ kg b.w. in normal saline). The methanol extract was administered orally. After extract administration, the animals were observed continuously for the first three hours, for any toxic manifestation like increased motor activity, salivation, acute convulsion, coma and death. Then, daily thereafter, for a total period of 2 weeks. On the sacrifice day, blood was withdrawn through cardiac puncture from the posterior vena cava of all rats under ether anesthesia.

\section{Hematological and biochemical analysis}

The blood was collected in two types of tubes: one with EDTA for hematological analysis and the other without any additives for biochemical analysis.

The blood for hematological assay was immediately analyzed using a hematological analyzer (Siemens' high-volume hematology analyzer; $\left.A D V I A^{\circ}{ }^{2120 i}\right)$. The parameters measured were red blood cell (RBC), mean cell volume $(\mathrm{MCV})$, red cell distribution width (RDW), hematocrit (HCT), platelets (PLT), mean volume of platelets (MPV), white blood cell (WBC), hemoglobin (HGB), mean corpuscular hemoglobin $(\mathrm{MCH})$, mean corpuscular hemoglobin concentration (MCHC), lymphocyte \% and lymphocytes number (lymph no).

The blood in the second tube was allowed for complete clotting for a minimum of $3 \mathrm{~h}$. The serums were collected and transferred into another tube to be centrifuged at $3000 \mathrm{rpm}$ at $4^{\circ} \mathrm{C}$ for $10 \mathrm{~min}$. The serums were immediately analyzed using a COBAS INTEGRA ${ }^{\oplus} 400$ plus auto analyzer. Biochemical parameters values determination was for liver profile were total bilirubin (BilT), alanine aminotransferase (ALT) and aspartate aminotransferase (AST). Renal profile parameters measured were urea, creatinine and other parameters were glucose and HDL-Cholesterol, LDL-Cholesterol, cholesterol and triglycerides for lipid profile.

\section{Experimental design and Gastric ulcer induction}

Male albino rats were divided into 5 groups of 5 animals each. Animals were fasted for $24 \mathrm{~h}$ before the study, ${ }^{5}$ but had free access to water. Animals in the control group received only normal saline. Methanol extract of G.Segetum at dose levels of 100, 250 and $500 \mathrm{mg} / \mathrm{kg}$ b. w. were given to animals (treatment groups). Omeprazole $(30 \mathrm{mg} / \mathrm{kg}$ ) was used as a standard. After $1 \mathrm{~h}$, all the animals received $0.5 \mathrm{~mL}$ of $90 \%$ ethanol. One hour after, the animals were sacrificed, and the stomach of each rat was taken, open according to the greater curvature by means of a chisel, washed with normal saline. Then fixed in a formal $10 \%$ for 5 minutes. The length of each ulcer was measured with a ruler in $\mathrm{mm}$, the number and severity of the ulcers were determined on a scale. ${ }^{6}$

\begin{tabular}{cc}
\hline 0 & no lesion \\
\hline 1 & $1-3$ small lesions $(\leq 10 \mathrm{~mm}$ length $)$ \\
2 & $1-3$ large lesions $(>10 \mathrm{~mm}$ length $)$ \\
3 & $1-3$ thickened lesions \\
4 & more than 3 small lesions \\
5 & more than 3 large lesions \\
6 & more than 3 thickened lesions \\
\hline
\end{tabular}

\section{Determination of ulcer index}

The ulcer index (UI) of each stomach was expressed as the sum of its scores. In addition, the percentage of protection (PP) was calculated according to the following formula: ${ }^{7}$
$\%$ Inhibition of Ulceration $=\frac{(\text { Ulcer index control }- \text { Ulcer index Test }}{\text { Ulcer index control }} \times 100$

\section{Egg albumin induced paw edema test}

The anti-inflammatory activity of the tested extract was evaluated in adult male albino rats by the fresh egg albumin induced paw edema method. ${ }^{8}$ Five groups of rats were fasted overnight before the experiment with free access to water. Rats of the first (control) and the second (standard) groups (5 animals each) were treated orally with the normal saline $(10 \mathrm{~mL} / \mathrm{kg})$ and the standard drug dichlofenac sodium $(30 \mathrm{mg} / \mathrm{kg})$ respectively.

Rats of the $3^{\text {rd }}$ to $5^{\text {th }}$ groups $(n=5)$ were orally administered the MEGS, the extract was given at three doses levels: 100, 250 and $500 \mathrm{mg} / \mathrm{kg}$ b.w. After $30 \mathrm{~min}$, acute inflammation was induced by sub plantar injection of $0.1 \mathrm{ml}$ fresh egg albumin in normal saline into the left hind paw of all rats. Paw thickness of each rat was measured in mm using a digital verniercaliper. The paw volume was measured at 1,2,3,4 and 5 hours after fresh egg albumin injection. Percentage of inhibition of edema was calculated as follows: ${ }^{9}$

$$
\% \text { Inhibition of edema }=\left[\frac{(\mathrm{tCn}-\mathrm{tC} 0)-(\mathrm{tTn}-\mathrm{tT} 0)}{(\mathrm{tCn}-\mathrm{tC} 0)}\right] \times 100
$$

Where: $\mathrm{tCn}=$ paw thickness at time point of control animal; $\mathrm{tC} 0=$ paw thickness before induction; $\mathrm{t} T \mathrm{n}=$ paw thickness at time point of treated animal; and $\mathrm{tT} 0=$ paw thickness before induction.

\section{Statistical analysis}

The results are expressed as the mean \pm SEM $(n=5)$. Statistical comparisons between the data for the control and treatment group were performed using the Student's $t$-test for the acute oral toxicity. Moreover, one-way analysis of variance (ANOVA) followed by Dunnet's test were used to compare the rest of results. Values were considered statistically significant at $\mathrm{p}<0.05$.

\section{RESULTS}

\section{Acute Oral Toxicity Study}

Acute toxicity studies of MEGS were carried out in female wistar rats at dose of $2000 \mathrm{mg} / \mathrm{kg}$ body weight. Oral administration of the extract was observed to have zero mortality and no adverse effects in any of the treated animals up to the dose of $2000 \mathrm{mg} / \mathrm{kg}$ body weight within $24 \mathrm{~h}$ of treatment.

Moreover, there was no toxic symptoms or death was observed even after 14 days of oral administration of MEGS to the rats. In case of hematological and biochemical parameters (Table 1 and 2) no significant changes were observed compared to the control group.

\section{Evaluation of Anti-ulcer activity}

Pre-treatment with ethanol at dose of $0.5 \mathrm{ml} / \mathrm{kg}$ showed ulcers in the control animals. However, animals treated with MEGS at 100,250 and $500 \mathrm{mg} / \mathrm{kg}$ b.w. doses showed significant $(\mathrm{P}<0.05)$ reduction in the ulcer index in a dose dependent manner (Table 3, Figure1). It showed 48.33, 60 and $88.33 \%$ of ulcer inhibition at the dose of 100,250 and $500 \mathrm{mg} / \mathrm{kg}$ b.w. respectively. Whereas omeprazole showed $81.66 \%$ ulceration inhibition. The anti-ulcer effect of G. segetum methanol extract at a dose of $500 \mathrm{mg} /$ $\mathrm{kg}$ b.w. was greater than that of omeprazole (30 mg/kg b.w.). 
Table 1: Effect of MEGS and normal slain on hematological parameters in rats during the acute toxicity study.

\begin{tabular}{ccc}
\hline Hematology parameters & Control & MEGS $2000 \mathrm{mg} / \mathrm{kg}$ BW \\
\hline RBC $(106 x \mu L)$ & $7.35 \pm 0.14$ & $7.59 \pm 0.20 \mathrm{~ns}$ \\
MCV $(\mathrm{fL})$ & $55.68 \pm 0.85$ & $55.8 \pm 0.69 \mathrm{~ns}$ \\
RDW(fL) & $13.18 \pm 0.26$ & $15.16 \pm 1.06 \mathrm{~ns}$ \\
HCT $(\%)$ & $40.92 \pm 0.48$ & $42.26 \pm 1.61 \mathrm{~ns}$ \\
PLT $\left(10^{3} / \mu \mathrm{L}\right)$ & $614.8 \pm 61.76$ & $654.4 \pm 81.03 \mathrm{~ns}$ \\
MPV $(\mathrm{fL})$ & $6.18 \pm 0.09$ & $6.78 \pm 0.44 \mathrm{~ns}$ \\
$\mathrm{WBC}\left(10^{3} / \mu \mathrm{L}\right)$ & $6.10 \pm 0.69$ & $6.22 \pm 0.70 \mathrm{~ns}$ \\
$\mathrm{HGB}(\mathrm{g} / \mathrm{dL})$ & $14.5 \pm 0.17$ & $14.7 \pm 0.41 \mathrm{~ns}$ \\
$\mathrm{MCH}(\mathrm{pg})$ & $19.74 \pm 0.25$ & $19.38 \pm 0.15 \mathrm{~ns}$ \\
MCHC $(\mathrm{g} / \mathrm{dL})$ & $35.46 \pm 0.17$ & $34.84 \pm 0.48 \mathrm{~ns}$ \\
Lymphocyte no & $4.24 \pm 0.51$ & $4.64 \pm 0.75 \mathrm{~ns}$ \\
Lymphocyte $\%$ & $69.08 \pm 2.43$ & $66.2 \pm 2.37 \mathrm{~ns}$ \\
\hline
\end{tabular}

Values are represented as mean $\pm \mathrm{SEM} ; \mathrm{n}=5$. ns: not significant compared to control.

Table 2: Effect of MEGS and normal slain on biochemical parameters in rats during the acute toxicity study.

\begin{tabular}{clc}
\hline Biochemical parameters & Control & MEGS $2000 \mathrm{mg} / \mathrm{kg}$ b.w. \\
\hline & Lipid profile & \\
Cholesterol (mmol/L) & $0.57 \pm 0.04$ & $0.66 \pm 0.02 \mathrm{~ns}$ \\
Triglycerides (mmol/L) & $0.83 \pm 0.10$ & $1.5 \pm 0.32 \mathrm{~ns}$ \\
HDL-Cholesterol (mmol/L) & $0.50 \pm 0.03$ & $0.56 \pm 0.04 \mathrm{~ns}$ \\
LDL-Cholesterol (mmol/L) & $0.06 \pm 0.01$ & $0.08 \pm 0.02 \mathrm{~ns}$ \\
Glucose (g/L) & $0.67 \pm 0.03$ & $0.72 \pm 0.01 \mathrm{~ns}$ \\
& Liver profile & \\
AST (U/L) & $131 \pm 5.54$ & $112 \pm 1.81 \mathrm{~ns}$ \\
ALT (U/L) & $86.2 \pm 7.13$ & $83.2 \pm 2.67 \mathrm{~ns}$ \\
Total bilirubin (mg/dL) & $0.76 \pm 0.04$ & $0.58 \pm 0.03 \mathrm{~ns}$ \\
& Rénal profile & \\
Urea (mg/L) & $0.30 \pm 0.01$ & $0.31 \pm 0.01 \mathrm{~ns}$ \\
Creat (mg/L) & $4 \pm 0.01$ & $3 \pm 0.00 \mathrm{~ns}$
\end{tabular}

Values are represented as mean \pm SEM; $\mathrm{n}=5$. $n s$ : not significant compared to control.

Table 3: Anti-ulcer effect of MEGS on Ethanol induced ulcers in rats.

\begin{tabular}{cccc}
\hline Groups & Treatment & Dose $(\mathrm{mg} / \mathrm{kg})$ & Ulcer Index (UI) \\
\hline I & Control & $10(\mathrm{~mL} / \mathrm{kg})$ & $3.4 \pm 0.245$ \\
II & MEGS & $100 \mathrm{mg}$ & $1.8 \pm 0.3742^{* *}$ \\
III & MEGS & $250 \mathrm{mg}$ & $1.4 \pm 0.400^{* * *}$ \\
IV & MEGS & $500 \mathrm{mg}$ & $0.4 \pm 0.2449^{* * *}$ \\
V & Omeprazole & $30 \mathrm{mg}$ & $0.6 \pm 0.2449^{* * *}$ \\
\hline
\end{tabular}

Values are represented as mean \pm SEM; $n=5 ;{ }^{*} \mathrm{p}<0.05,{ }^{* *} \mathrm{p}<0.01$ and ${ }^{* * *} \mathrm{p}<0.001$ compared to control.

\section{Evaluation of Anti-inflammatory activity}

MEGS showed a good anti-inflammatory activity (Table 4, Figure 2), suppressing the egg albumin induced edema both at the early and later phases. The highest inhibition of edema was obtained with $500 \mathrm{mg} / \mathrm{kg}$ b.w. $(52.67 \%)$ at the $5^{\text {th }}$ hour after drug administration. The MEGS at the dose level of $100 \mathrm{mg} / \mathrm{kg}$ b.w. did have a significant anti-inflammatory

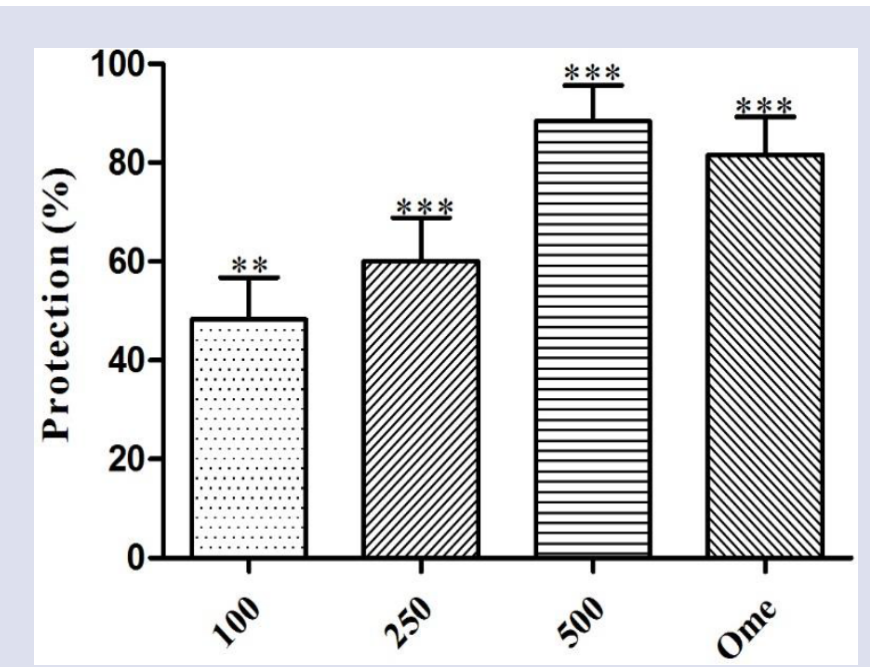

Figure 1: Percent of the Anti-ulcer effect of MEGS on Ethanol induced ulcers in rats. Ome(Omeprazole). Values are represented as mean \pm SEM ( $n=5) .{ }^{*} p<0.05,{ }^{* *} p<0.01$ and ${ }^{* * *} p<0.001$ compared to control.
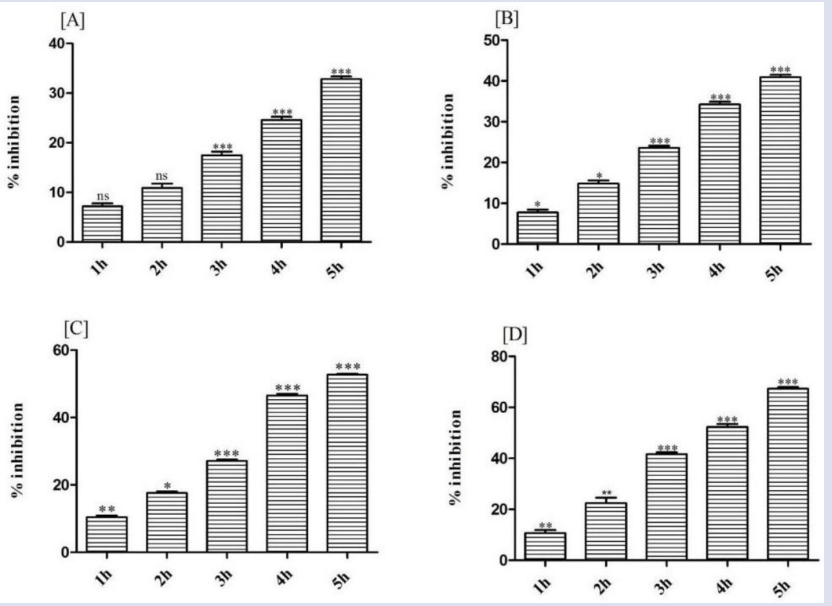

Figure 2: Anti-inflammatory effect of MEGS on egg-albumin induced paw edema test; $[A] 100,[B] 250,[C] 500 \mathrm{mg} / \mathrm{kg}$ b.w. and [D] Dichlofenac sodium. Values are represented as mean \pm SEM $(n=5)$. ${ }^{*} p<0.05$, ${ }^{* *} p<0.01$ and ${ }^{* * *} p<0.001$ compared to control.

activity after $1 \mathrm{~h}$ and $2 \mathrm{~h}$ of treatment, but it showed a significant average activity after $3 \mathrm{~h}, 4 \mathrm{~h}$ and $5 \mathrm{~h}(\mathrm{P}<0.001)$. The MEGS at 250 and $500 \mathrm{mg} / \mathrm{kg}$ b.w. significantly inhibited the edema_formation induced by the injection of egg albumin after $1 \mathrm{~h}(\mathrm{P}<0.05)$ and $(\mathrm{P}<0.01)$ respectively and it showed more significant anti-inflammatory activity in the second phase of inflammation $3 \mathrm{~h}$ to $5 \mathrm{~h}(\mathrm{P}<0.001)$.

\section{DISCUSSION}

In general, the safety studies on herbal medicines have been carried out by performing acute and sub-acute toxicity tests in laboratory animals. ${ }^{10}$ in the present acute toxicity study, the oral administration of a single dose $2000 \mathrm{mg} / \mathrm{kg}$ of MEGS did not reveal any signs of toxicity or mortality in any animal during the entire observation period. Hematological and 
Marref, et al.: Acute Toxicity, Antiulcer and Anti-inflammatory Effects of Methanol Extract of Gladiolus segetum in Rats

Table 4: Anti-oedematous effect of MEGS on egg-albumin induced paw edema in rats.

\begin{tabular}{ccccccc}
\hline Treatment & $\begin{array}{c}\text { Dose }(\mathrm{mg} / \\
\mathbf{k g})\end{array}$ & \multicolumn{5}{c}{$\Delta$ paw edema $(\mathrm{mm})$} \\
\cline { 3 - 7 } & & $\mathbf{1 h}$ & $\mathbf{2 h}$ & $3 \mathrm{~h}$ & $4 \mathrm{~h}$ & $5 \mathrm{~h}$ \\
\hline Control & $\mathbf{1 0 m l} / \mathbf{k g}$ & $5.43 \pm 0.10$ & $4.926 \pm 0.21$ & $4.642 \pm 0.15$ & $4.09 \pm 0.17$ & $3.802 \pm 0.13$ \\
$\begin{array}{c}\text { Dichlofenac } \\
\text { sodium }\end{array}$ & $\mathbf{3 0}$ & $4.96 \pm 0.55^{* *}$ & $3.81 \pm 0.12^{* *}$ & $2.71 \pm 0.08^{* * *}$ & $1.946 \pm 0.07^{* * *}$ & $1.24 \pm 0.03^{* * *}$ \\
MEGS & $\mathbf{1 0 0}$ & $5.04 \pm 0.12 \mathrm{~ns}$ & $4.396 \pm 0.22 \mathrm{~ns}$ & $3.828 \pm 0.11^{* * *}$ & $3.082 \pm 0.12^{* * *}$ & $2.55 \pm 0.09^{* * *}$ \\
MEGS & $\mathbf{2 5 0}$ & $5.014 \pm 0.10^{*}$ & $4.196 \pm 0.18^{*}$ & $3.546 \pm 0.10^{* * *}$ & $2.69 \pm 0.11^{* * *}$ & $2.24 \pm 0.07^{* * *}$ \\
MEGS & $\mathbf{5 0 0}$ & $4.87 \pm 0.09^{* *}$ & $4.06 \pm 0.17^{*}$ & $3.38 \pm 0.11^{* * *}$ & $2.18 \pm 0.10^{* * *}$ & $1.8 \pm 0.07^{* * *}$ \\
\hline
\end{tabular}

Values are represented as mean \pm SEM; $\mathrm{n}=5 ;{ }^{*} \mathrm{p}<0.05,{ }^{* *} \mathrm{p}<0.01$ and ${ }^{* *} \mathrm{p}<0.001$ compared to control.

biochemical parameters did not change significantly as compared to the control group. These results showed that the MEGS is safe and explained the utilisation of the plant in traditional medicine.

Ulcers are caused by the imbalance between aggressive and defensive factors of the gastric mucosa. Different therapeutic agents including plant extracts are used to inhibit the gastric acid secretion or to stimulate the mucosal defense mechanism. Mucosal defense mechanism is stimulating by increasing the mucus production protecting the surface epithelial cells or interfering with the prostaglandins synthesis. ${ }^{11}$

The mechanisms involved in the gastric lesions induced by ethanol are complex and numerous, with venoconstriction, artery dilation, autacoids liberation. ${ }^{12,13}$ Ethanol has been reported to cause disturbances in gastric secretion, damage to the mucosa, alterations in the permeability, gastric mucus depletion and free radical production. This is attributed to the release of superoxide anion and hydroperoxy free radicals during metabolism of ethanol as oxygen derived free radicals has been found to be involved in the mechanism of acute and chronic ulceration in the gastric mucosa. ${ }^{14}$

Gastric lesion formation induced by ethanol may be due to stasis in gastric blood flow which contributes to the development of the haemorrhage and necrotic aspects of tissue injury. Alcohol rapidly penetrates the gastric mucosa apparently causing cell and plasma membrane damage leading to increased intra cellular membrane permeability to sodium and water. The massive intracellular accumulation of calcium represents a major step in the pathogenesis of gastric mucosal injury. This leads to cell death and exfoliation in the surface epithelium. ${ }^{15}$ The MEGS protect gastric mucosa of the rats from ulceration induced by ethanol may be due to both reductions in gastric acid secretion and gastric cytoprotection. Inflammation is a complex biological response of vascular tissues invasion by an infectious agent, antigen challenge, physical, chemical or traumatic damage. Although inflammation is a defence mechanism, the complex events and mediators involved in the inflammatory reactions can induce, maintain or aggravate many diseases. ${ }^{16}$ The non-steroidal anti-inflammatory drugs (NSAIDS) possess anti-inflammatory action for treating several inflammatory conditions including rheumatoid arthritis, osteoarthritis and musculoskeletal disorders, but prolonged use of NSAIDS has some associated adverse effects such as nausea, fluid retention, bleeding and gastric lesion. ${ }^{17}$ Therefore, new anti-inflammatory drugs devoid of these side effects are being researched on as alternatives to NSAIDS.

The earlier studies had indicated the use of egg-albumin as a phlogistic agent causes edema. Carrageenan and egg albumin induced paw edema methods are suitable for screen agents for anti-inflammatory activity, which are frequently used to assess the antioedematous effect of natural products. ${ }^{18,19}$

Several inflammatory mediators like complement, histamine, kinins, prostaglandins and pro-inflammatory cytokines have been suggested to play a role in the mechanism of inflammation..$^{20-21}$ Edema, which develops after egg albumin injection, is a biphasic event. The initial phase is attrib- uted to the release of histamine and serotonin and lasting up to $2 \mathrm{~h}$. While the later phase, occurring from 3 to $5 \mathrm{~h}$ after the injection of the irritant is induced by bradykinin, protease, prostaglandins and lysosome. ${ }^{22}$

It has been reported that the egg albumin acts prominently on the mast cells. Edema induced by it, appears to be mediated by histamine and serotonin. Inflammatory processes in which mast cells are prominently involved are inhibited by antihistaminic and antiserotonin compounds. The anti-oedematous effect showed by MEGS was significant during the first phase of edema development and significantly maintained in the second phase of the edema development, suggesting an inhibitory effect on the release of active pain substance such as histamine, serotonin, polypeptides or prostaglandins. It is assumed that at least some of these mediators are subjects of inhibition by the methanol extract of aerial parts of G. segetum.

Phytochemical study of the aerial parts of the plant showed abundance of flavonoids, saponins, anthraquinones, triterpenes and phytosterols. ${ }^{23,24}$

Flavonoids have been reported to act in the gastrointestinal tract, having antispasmodic, anti-secretary, anti-diarrheal, antiulcer, and antioxidant properties. Flavonoids are among the cytoprotective materials for which anti-ulcer genic efficacy has been extensively confirmed. They protect the gastric mucosa against a variety of ulcer genic agents via several mechanisms of action, mainly free-radical scavenging and antioxidant properties, increased_mucus production, antisecretory action, and inhibition of the Helicobacter pylori growth. ${ }^{25}$ Furthermore, flavonoids have been reported to possess potent inhibitory effect on enzymes involved in the production of the chemical mediators of inflammation and metabolism of arachidonic acid. ${ }^{26,27}$ The presence of different classes of secondary metabolites especially flavonoids may be responsible for the anti-inflammatory and the anti-ulcer activities of this plant.

\section{CONCLUSION}

The present study confirmed the ethno pharmacological use of G. segetum as an antiulcer agent, that the methanol extract of aerial parts of G. segetum possess a potent ulcer healing effect and protection against characteristic lesions produced by ethanol administration and antiinflammatory properties. Further studies are necessary to elucidate the mechanisms involved in its biological activity and the mode of action on gastric acid secretion, gastric cytoprotection and understand the precise mechanism of action in anti-inflammatory activities by the methanol extract of aerial parts of G.segetum.

\section{CONFLICT OF INTEREST}

The authors confirm that this article content has no conflict of interest.

\section{ACKNOWLEDGEMENT}

The authors wish to express thanks to the general directorate for scientific research and technological development (DGRSDT) of the Algerian Minister of Higher Education and Scientific Research for providing a research grant. 


\section{ABBREVIATIONS}

MEGS: Methanol Extract of Gladiolus Segetum; Ome: Omeprazole ; EDTA: Ethylene Diamine Tetra Acetic Acid.

\section{REFERENCES}

1. Akhtar $\mathrm{AH}$, Ahmad KU. Anti-ulcerogenic evaluation of the methanolic extracts of some indigenous medicinal plants of Pakistan in aspirinulcerated rats. J Ethnopharmacol. 1995;46(1):1-6.

2. AlKofahi $A, A t t a A H$. Pharmacological screening of the antiulcerogenic effects of Some Jordanian Mecicinal Plants in rats. J Ethnopharmacol. 1999;67(3):341-5.

3. Fernandez-Arche A, Saenz MT, Arroyo M, De la Puerta R, Garcia MD. Topical anti-inflammatory effect of tirucallol, a triterpene isolated from Euphorbia lactea latex. Phytomedicine. 2010;17(2):146-8.

4. Oecd/ocde. Ligne directrice de l'ocde pour les essais de produits chimiques ocde 301. 2013;(1):9

5. Togola A, Karabinta K, Dénou A, Haidara M, Sanogo R, Diallo D. Effet protecteur des feuilles de Opilia celtidifolia contre l'ulcère induit par l'éthanol chez le rat. Int J Biol Chem Sci. 2014;8(6):2416-23

6. Magistretti MJ, Conti M, Cristoni A.: Antiulcer activity of an anthocyanidin from Vaccinum myrtillus. Arzneim Forsch. IDrugRes.1988;38(5):686-90.

7. Dashputre NL, Naikwade NS. Evaluation of Anti-Ulcer Activity of Methanolic Extract of Abutilon indicum Linn Leaves in Experimental Rats. International Journal of Pharmaceutical Sciences and Drug Research. 2011;3(2):97-100.

8. Anosike C A, Obidoa O, Ezeanyika LUS. The anti-inflammatory activity of garden egg (Solanum aethiopicum) on egg albumin —induced oedema and granuloma tissue formation in rats. Asian Pac J Trop Med. 2012;5(1):62-6.

9. Preethia KC, Kuttanb G, Kuttan R. Anti-inflammatory activity of flower extract of Calendula officinalis Linn. and its possible mechanism of action. Indian J Exp Biol. 2009;47(2):113-20

10. Fennell CW, Lindsey KL, McGaw LJ, Sparg SG, Stafford GI, Elgorashi EE, et al. Assessing African medicinal plants for efficacy and safety: Pharmacological screening and toxicology. J Ethnopharmacol. 2004;94(2-3):205-17.

11. Ghangale GR, Tushar M, Jadhav ND. Evaluation of antiulcer activity of ocimum sanctum in rats. Vet World. 2009:2(12):465-6.

12. Oates PJ, Hakkinen PJ. Gastroenterology. 1988;94(1):10-21.
13. Llesuy SF. MG. Repetto. Brazil J Med Biol Res. 2002;35(5):523-34

14. Jude EO, Paul A. Antiulcer and Anticonvulsant Activity of Croton Zambesicus. J Pharm Sci. 2009;22(4):384-90

15. Raju D. et al. Evaluation of Anti-ulcer activity of methanolic extract of Terminalia chebula fruits in experimental rats. J Pharm Sci Res. 2009;1(3):101-7.

16. Ferrero-Miliani L, Nielson $\mathrm{OH}$, Andersen PS, Girardin SE. Chronic inflammation: importance of NOD2 and NALP3 in interleukin-1ß generation. Clin Expe Immunol. 2007;147(2):227-35.

17. Abebe W. Herbal medication: potential for adverse interactions with analgesic drugs. J Clin Pharm Ther. 2002;27(6):391-401.

18. Akah PA, Okogun JI, Ekpendu TO. Antioedema and analgesic activity of Diodia scandansextract in rats and mice. Phytother Res.1993;7(4):317-9.

19. Amos S, Chindo B, Edmond I, Akah P, Wambebe C, Gamaniel K. Anti-inflammatory And anti-nociceptive effects of Ficusplatyphylla extracts in mice and rats. J Herbs Spices Med. 2002;9(1):47-53.

20. Rosa DM, Giroud JP, Willoughby DA. Studies on the mediators of the acute inflammatory response induced in rats in different sites by carrageenin and Turpentine. J Pathol. 1971;104(1):15-29.

21. Hischelmann $\mathrm{R}$, Bekemeier $\mathrm{H}$. Effect of catalase, peroxidase, superoxide dismutase and 10 scavengers of oxygen radicals in Carrageenin oedema and in adjuvant arthritis of rats. Experientia. 1981;37(12):1313-4.

22. Wallace JM. Nutritional and botanical modulation of the inflammatory cascade: Eicosanoids, cyclooxygenase and lipoxygenase-as an adjunct in cancer therapy. Integr Cancer Ther. 2002;1(1):7-37.

23. Abdessemed D, Dibi A. Secondary metabolite from Gladiolus segetum. J Chem Pharm Res. 2013:5(12):939-41.

24. Mohamed KM. Chemical Constituents of Gladiolus Segetum Ker-Gawl. Bull Pharm Sci. 2005;28(1):71-8.

25. Fatima S, Heena ST, Qureshi AS. Evaluation of Anti-Ulcer Activity of $70 \%$ Hydro-Ethanolic leaf extract of Argemone mexicana Linn . In Experimental Rats. Journal of Pharmacy. 2016:6(4):41-50.

26. Oweyele VB, Oloriegbe YY, Balaogun EA, Soladoye AO. Analgesis and anti-inflammatory properties of Nelsonia canescens leaf extract. J Ethnopharmacol. 2005:99(1):153-6.

27. Saleem TM, Azeem AK, Dilip C, Sankar C, Prasanth NV, Duraisami R. Antiinflammatory activity of the leaf extacts of Gendarussa vulgaris Nees. Asian Pac J Trop Biomed. 2011;1(2):147-9.

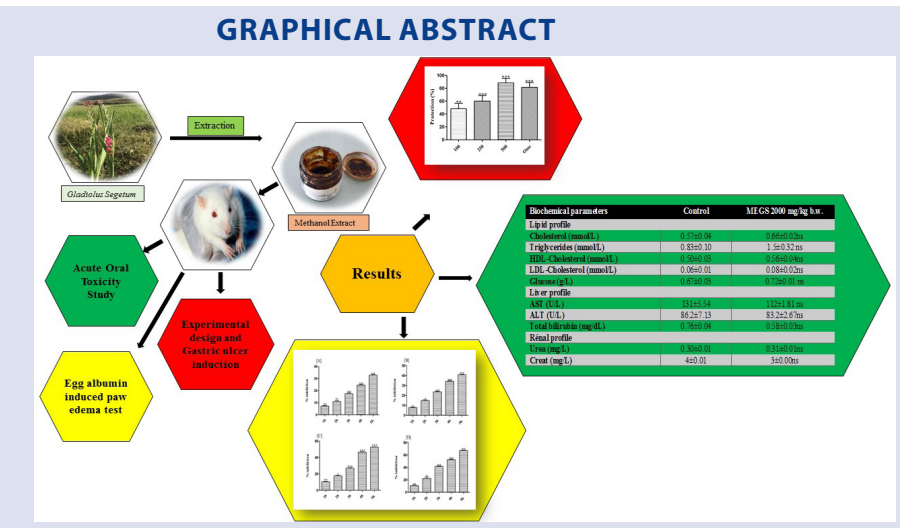

\section{SUMMARY}

- The anti-ulcer effect of methanol extract of Gladiolus segetum at a dose of 500 $\mathrm{mg} / \mathrm{kg}$ b.w. was greater than that of omeprazole (30 $\mathrm{mg} / \mathrm{kg} \mathrm{b.w.).}$

- Metanol extract of Gladiolus segetum showed a good anti-inflammatory activity,suppressing the egg albumin induced edema both at the early and later phases.

- There was no toxic symptoms or death was observed even after 14 days of oral administration of MEGS to the rats.

- The present study confirmed the ethnopharmacological use of Gladiolus segetum as an antiulcer and anti-inflammatory agent.

\section{ABOUT AUTHORS}

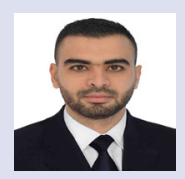

Salah Eddine Marref is currently a PhD student at University of Batna 02, ALGERIA. Biotechnology Laboratory of Bioactive Molecules and Cell Physiopathology.

Dr.Naima Benkiki leads a research team in the Biotechnology Laboratory of Bioactive Molecules and Cell Physiopathology. University of Batna 02, ALGERIA.

Mohamed Akram Melakhessou is currently a PhD student at University of Batna 02, ALGERIA.Biotechnology Laboratory of Bioactive Molecules and Cell Physiopathology.

Soumia Bouzidi is currently a PhD student at University of Batna 02, ALGERIA.Biotechnology Laboratory of Bioactive Molecules and Cell Physiopathology.

Cite this article: Marref SE, Benkiki N, Melakhessou MA, Bouzidi S. Acute Toxicity, Antiulcer and Anti-inflammatory Effects of Methanol Extract of Gladiolus Segetum in Rats. Pharmacog J. 2018;10(4):758-62. 